\title{
Predicting Savings From Adolescence to Young Adulthood: A Propensity Score Approach
}

\author{
Terri L. Friedline \\ William Elliott \\ Ilsung Nam \\ University of Pittsburgh, School of Social Work
}

\begin{abstract}
This paper examines the progression of savings between adolescence and young adulthood. Using data from the Panel Study of Income Dynamics, we ask whether the likelihood of having a savings account in young adulthood and the amount of savings can be significantly predicted by two factors: having a savings account during adolescence and having parents who own assets. Descriptive statistics reveal that adolescents with savings accounts are more often White, employed, and live in households in which the head is married, has more education, and owns assets. Propensity score analyses confirm that young adults are more likely to have a savings account when they have a savings account as adolescents. Some evidence suggests that adolescents whose parents have savings on their behalf and have higher net worth are more likely to have higher amounts of savings as young adults. Findings suggest that parents play an important role in modeling saving habits for adolescents. Further, our findings suggest that having a savings account in adolescence leads to an increased likelihood of having a savings account in young adulthood; however, this finding requires confirmation in future research.
\end{abstract}

\section{Keywords: savings, assets, adolescence, young adults, Child Development Accounts (CDAs), Panel Study of Income Dynamics (PSID)}

The old adage, "A penny saved is a penny earned," reminds us that saving, even small amounts, provides financial benefits. Many people agree that the decision to save is wise; however, for a variety of reasons, few people in the United States adhere to the wisdom extolled in this proverb. Trends at the turn of the 21 st century point out that the personal savings rate of U.S. families declined from $8 \%$ in the 1980 s and 1990 s to between approximately $0.5 \%$ and $1.8 \%$ in 2001 (Bernheim \& Scholz, 1993; Bureau of Economic Analysis, 2009; Organisation for Economic Co-Operation and Development [OECD], 2009; Shafer, Elmeskov, \& Tease, 1992). Since 2002, the average personal savings rate in the United States has remained at nearly 5\% (Bureau of Economic Analysis, 2009; OECD, 2009). These percentages are far below the historic average of U.S. personal savings of $10 \%$ as well as that of international comparisons. For example, Japan's personal savings rate, which peaked at $40 \%$ in the early 1970 s, remains between $20 \%$ and $30 \%$, and the personal savings rates for countries in the European Union consistently hover around 20\% (Bosworth, 2006).

In recent years, the low savings rate in the United States has led to an increased emphasis on research and policies to promote savings. For example, President Bush spoke of the "Ownership Society" and proposed to expand savings opportunities through the creation of Retirement Savings Accounts (RSAs) and Lifetime Savings Accounts (LSAs; Bush, 2004). President Obama has continued the focus on increasing savings by proposing policies such as AutoIRAs, an expanded Saver's Credit, and reforming asset-limit rules that determine eligibility for public assistance to encourage rather than discourage savings (Cramer, Huelsman, King, LopezFernandini, \& Newville, 2010).

Research and policy on savings often overlook young people as agents who are capable of saving (e.g., Hogarth, Anguelov, \& Lee, 2003, 2005). In part, this oversight is due to the predominant model of savings in economics: the life-cycle hypothesis (Modigliani \& Brumberg, 1954). Life-cycle hypothesis theorists suggest that over a lifetime, a person's pattern of savings looks like an inverted U-shape (e.g., Harrod, 1948). That is, when people are young, they have little money to save and end up borrowing more; when they are middle-aged, they have higher incomes that enable them to save more; and when they are older and their incomes decline, they have to spend their savings. From this perspective, it makes little sense to talk about young people having money to save. 
In contrast to research on the life-cycle hypothesis, some researchers have focused on young people's savings and have examined the benefits of beginning savings at an early age. This research has suggested that young people think about saving for short-term goals as early as 6 years old, and understand saving for longterm goals as early as age 12 years (Sonuga-Barke \& Webley, 1993; Webley, Burgoyne, Lea, \& Young, 2001). By age 6 years, young people learn that savingalong with exercising self-control, thrift, and patienceare good things; although young children do not necessarily enjoy saving nor are they very good at it (Sherraden, Johnson, Guo, \& Elliott, 2010; Sonuga-Barke \& Webley, 1993; Webley, Levine, \& Lewis, 1991). Between 6 and 12 years of age, young people develop greater abstract economic reasoning, become increasingly adept at understanding the value of saving, and learn that saving in a bank not only yields interest but also protects their money from being spent by themselves or others (Sonuga-Barke \& Webley, 1993; Webley et al., 1991). Thus, evidence suggests that young people benefit from saving as early as age 12 years, and that somewhere between the ages of 6 and 12 years they begin to grasp the relationship between saving and future opportunity.

Despite the research on the age at which young people may begin to benefit from saving, we know little about young people who save and whether saving at a young age improves young people's long-term financial well-being. This article addresses this knowledge gap. We begin with a brief review of relevant research on adults' savings to provide a context for variables commonly used to predict savings. Next, we discuss research on young people's saving behaviors and provide a theoretical foundation for some of the benefits associated with savings. This discussion is followed by an analysis of whether having a savings account in adolescence predicts saving behaviors later in life (i.e., having a savings account or the amount saved in young adulthood) using longitudinal data from the Panel Study of Income Dynamics and propensity score analyses. Finally, the discussion and conclusion tie the results of this study to previous research and describe implications for policy and future research.

\section{Research on Savings}

Reviewing research on adults' savings is a needed first step because this body of research describes how savings and saving behaviors are commonly conceptualized and it identifies variables that are often significantly related to savings in the adult population. In addition, this research is relevant to the present study because it offers insight into variables that may be simi- larly related to young people's savings and behaviors, an area in which little research has been done.

\section{Research on Adults' Saving}

Research has linked the ability to save in adulthood to a number of variables ranging from demographic and psychological to behavioral and institutional factors (Beverly, 1997). For example, demographic variables such as level of education (Bernheim \& Garrett, 1996; Bernheim, Garrett, \& Maki, 2001; Diamond \& Hausman, 1984; Solmon, 1975) and household size (Alessie \& Teppa, 2010; Carr Steelman \& Powell, 1989, 1991) are used to predict saving. However, the independent effects of race on saving are less evident (Conley, 1999). Moreover, research has shown an association of saving with psychological variables such as time preference (Frederick, Loewenstein, \& O'Donoghue, 2003; Lawrence, 1991), future orientation (Howlett, Kees, \& Kemp, 2008), and expectations (Furnham, 1985; Katona, 1975). Further, socialization and habit of saving have been linked to adults' saving (Alessie \& Teppa, 2010; Miller, 1995; Pritchard, Myers, \& Cassidy, 1989). Adults' ability to save has also been associated with a variety of household financial and asset variables, including income (Grinstein-Weiss \& Sherraden, 2004; Lunt \& Livingstone, 1991; Summers, Carroll, \& Blinder, 1987), income uncertainty (Alessie \& Teppa, 2010), liquidity constraints (Alessie \& Teppa, 2010; Deaton, 1991), and home ownership (Grinstein-Weiss \& Sherraden, 2004; Kotlikoff, Spivak, \& Summers, 1982). Recently, researchers have used institutional variables, such as access to and incentives for saving, to predict adults' ability to save (Beverly \& Sherraden, 1999; Grinstein-Weiss \& Sherraden, 2004; GrinsteinWeiss, Yeo, Despard, Casalotti, \& Zhan, 2010; Schreiner, Clancy, \& Sherraden, 2002; Ssewamala \& Sherraden, 2004).

\section{Research on Young People's Saving}

Although the life-cycle hypothesis is the predominant theory of savings in the United States, encouraging young people's savings is not a new topic. Some of the earliest savings programs intended for young people began in the late 1800s through school-based initiatives such as the School Savings Banking in New York Public Schools (Cruce, 2001; Tucker, 1991). Since that time, opportunities for financial education and savings have expanded (Cruce, 2001, 2002). Currently, a range of public and private initiatives supports savings among young people (American Bankers Association, 2009; Council for Economic Education, 2010; Junior Achievement, 2009; Young Americans Center for Financial Education, 2010). For instance, the Young Americans Center for Financial Education (YACFE) based in 
Denver, Colorado provides services including financial summer camps, weekend activities, and a bank designed specifically for young people 21 years and younger (YACFE, 2010). The Young Americans Bank serves approximately 15,000 young people nationwide and offers the same types of services as a typical bank, including checking and savings accounts, loans, and credit card services (Cline, 2005; Young Americans Bank, 2009; YACFE, 2010). In addition, the American Bankers Association promotes young people's savings by offering online tutorials, lessons on savings, and partnerships with banks (American Bankers Association, 2009). However, initiatives are often limited to financial education or banking services for young people without providing evidence that access to services translates into savings. Further, little is known regarding who benefits from these services and why some young people save and others do not.

Young people's savings has begun to receive more research attention in recent years. Research initiatives regarding young people's savings range from independent studies to large-scale, privately funded programs. Most research has tended to focus on three age categories: (a) birth to 12 years, (b) 12 to 18 years, and (c) 18 to 22 years of age. These age categories are by no means restrictive; however, given the availability of data or the purposes of the studies, researchers have chosen to limit the ages of their samples to roughly one of these three categories.

Young people-even the very young - can be active agents in the process of saving and can be successful in such endeavors. The Saving for Education, Entrepreneurship, and Downpayment (SEED) program is a privately funded effort that began in 2004, and is one of the first programs in the United States to specifically measure young people's use of savings accounts within financial institutions (Masa, 2009). Currently, SEED has more than 1,000 participants $(N=1,171)$, the majority of whom are 10 years or younger $(75 \%)$, are from low- to moderate-income families, and receive subsidized matched accounts in which either the young person or their caregivers save toward future expenses such as education, small business start-up costs, or down payment on a home (Mason, Nam, Clancy, Loke, \& Kim, 2009). By 2007, SEED participants had accumulated an average of $\$ 1,518$ toward their long-term goals, including net deposits and the SEED match contribution (Mason et al., 2009). When examining savings among SEED participants, researchers found that, similar to research findings for adults, the total amount saved was significantly predicted by household characteristics such as a single head of household and heads of households with education at the bachelor's level or higher (Mason,
Nam, Clancy, Kim \& Loke, 2010). In contrast to the weak evidence for race as a predictor of savings among adults (Conley, 1999), Mason and colleagues (2010) found a significant relationship between young people's race and savings amounts. Mason and colleagues' results indicated that, as compared with being Black or Latino, being White or Asian was a positive predictor of the total amount saved. Moreover, these researchers found that home ownership was a significant predictor of the total amount saved (Mason et al., 2010).

Studies have shown that by approximately 12 to 18 years of age a majority of young people have some amount of savings (Elliott, Jung, \& Friedline, 2010; Furnham, 1999; Mandell, 2008; Warnarr \& Van Praag, 1997). For example, in a 2008 survey of high-school seniors conducted by Jump\$tart, nearly $29 \%$ of young people had a savings account, $12 \%$ had a checking account, and approximately $34 \%$ had both a savings and a checking account. The remaining $30 \%$ of the students were unbanked, that is, they did not have any form of a bank account (Mandell, 2008). Similarly, descriptive results from the Panel Study of Income Dynamics (PSID) have shown that $67 \%$ of the young people surveyed (the average young person sampled was in ninth grade) had savings (Elliott, Jung, et al., 2010).

In a study of 1,619 high school seniors and their parents, Pritchard et al. (1989) found more than 79\% of young people put none or only a small amount of money in savings as compared with the nearly $21 \%$ of the students who reported putting about half or most of their money in savings. Results also indicated that young people's savings was significantly related to factors such as their race, gender, high school grades, and plans beyond high school. Young people whose future plans included college or post-secondary training (i.e., what researchers refer to as future orientation) saved greater amounts than those who had no plans for education beyond high school (Pritchard et al., 1989). Pritchard and colleagues' analyses included parent or caregiver characteristics, and their results showed that the head of household's socioeconomic status, education level, and savings were significantly related to young people's savings. However, the number of hours a young person worked per week and their related earnings were not significantly associated with savings (Pritchard et al., 1989).

Few researchers have examined whether savings among young people leads to a greater likelihood of saving or having larger amounts of money saved as young adults. To date, such research has been limited for several reasons. First, researchers have created approximate age categories for analyzing savings and 
have not examined the continuous progression in savings from adolescence (or earlier) into young adulthood (Furnham, 1999; Mandell, 2008; Pritchard et al., 1989). Second, even when research has used a longitudinal design to examine savings based on age, such research has often failed to include the same group of participants, but rather has drawn from different participant groups that represent progressions in age categories (Berti \& Bombi, 1981a, 1981b; Otto, Schots, Westerman, \& Webley, 2006; Webley et al., 1991). Third, savings has often received secondary consideration in research, and consequently, savings has not been used as a dependent variable (Elliott, 2009; Elliott, Jung, et al., 2010; Mandell, 2008; Warnarr \& Van Praag, 1997). Therefore, most of the research findings have been descriptive only and research has continued to overlook the exploration of what factors predict savings among young people. Fourth, our thorough search of the literature revealed little research that has examined which factors might predict the amounts of young people's savings (Leiser \& Ganin, 1996; Mason et al., 2010; Webley \& Nyhus, 2006). Fifth, other variables, which have been shown to be important predictors of savings in adulthood (e.g., household income, household size, net worth, or home ownership), have not been consistently controlled for in studies on young people (Furnham, 1999; Warnarr \& Van Praag, 1997). Finally, most research efforts on young people's savings have used nonexperimental or quasi-experimental designs (Elliott, Jung, et al., 2010; Mason et al., 2010). However, research using an experimental design with random assignment to reduce potential selection bias may be one of the best ways to examine the relationship between young people's savings at different time points (Engel \& Schutt, 2005; Rosenbaum, 2002b). Given the cost-prohibitive nature of randomly assigning savings accounts to a representative sample of young people, experimental designs are rarely used in this area.

This article addresses these limitations in several important ways. We examine the progression of savings (including having a savings account and the amount saved) between adolescence and young adulthood with the same group of young people, controlling for a variety of adolescent, parent, and asset variables. We use propensity score analyses to account for observed selection into groups of adolescents with (i.e., treated) and without (i.e., nontreated) savings accounts. In addition, we test the sensitivity of the results due to omitted covariates, which is also referred to as unobserved heterogeneity. However, because so little research exists in this area, this study remains largely exploratory in nature.

\section{Theory on Young People's Saving Habits}

Although there are many theories of savings, we focus on two theoretical perspectives to help explain saving among young people: behavioral economics and financial capability. Behavioral economics, a developmental approach to saving behaviors, suggests that young people are socialized into the world of economics at a young age. According to behavioral economists, young people's socialization begins by differentiating between coins and other objects and learning that money is related to purchasing. However, it is typically not until a young person reaches 6 years that he or she can differentiate between coin denominations and comprehend that more coins usually buy more items (Berti \& Bombi, 1981a). From this early socialization, young people's understanding of money and economics expands to acknowledge the benefits of saving to make larger purchases. However, these very young people are less able and less interested in practicing saving strategies than their older counterparts (Otto et al., 2006; Webley et al., 1991; Webley \& Plaisier, 1998). Between the approximate ages of 6 and 12 years, young people's emergent conception of money is replaced by the matured conception that money can be personally regulated. Thus, young people begin to engage in more complex saving and spending strategies by approximately 12 years (Berti \& Bombi, 1981a; Nyhus \& Webley, 2006; Otto et al., 2006; Webley et al., 1991). Notably, 12 years is same age at which the PSID begins asking young people questions regarding their saving and spending habits. To date, the literature has consistently documented this age trend in the development of young people's economic comprehension (Berti \& Bombi, 1981a, 1981b; Harrah \& Friedman, 1990; Jahoda \& France, 1979; Jahoda, 1981; Leiser, 1983; Leiser, Sevón, \& Lévy, 1990; Nyhus \& Webley, 2006; Otto et al., 2006; Strauss, 1952; Waines, 1984; Ward, Wackman, \& Wartella, 1977; Webley et al., 1991).

According to Johnson and Sherraden (2006), financial capability is the ability for people "to understand, assess, and act in their best financial interest" (p. 124). Two components are important in developing financial capability: financial literacy (i.e., the knowledge, skills, confidence, and motivation needed to act) and inclusion in or access to financial institutions (Johnson \& Sherraden, 2006; Sherraden, 2010). According to Sherraden (2010), young people develop financial literacy through economic socialization. Economic socialization is the process through which young people learn the values, attitudes, and behaviors that guide their financial decision making (Schuchardt et al., 2009; Sherraden, 2010). Young people learn about the economic world early on in life (Furnham, 1999), primarily from their 
families (Beutler \& Dickson, 2008), but increasingly through the media (McNeal, 1987). We contend that families teach young people about the importance of saving through modeling. That is, young people learn about saving, at least in part, by observing their parents' saving habits. This study used a proxy for parents' saving habits: whether parents had savings for their children. Given this proxy, we propose that adolescents whose parents have savings on their behalf are more likely to have savings of their own as young adults and to have saved larger amounts than adolescents whose parents do not have savings on their behalf. Some evidence exists to support this contention. Pritchard et al. (1989) found that parents' saving habits were significantly related to whether a group of employed highschool students had savings.

In addition to financial literacy, Johnson and Sherraden (2006) have suggested that financial capability requires access to financial products. We suggest that adolescents who have access to savings are more likely to have access to financial products in young adulthood because they have an established relationship with banking institutions. Based on this contention, we propose that adolescents with savings accounts are more likely to have savings accounts as young adults and to have saved larger amounts than adolescents who do not have savings accounts. Limited evidence exists to support this contention. Kotlikoff and Bernheim (2001) found that people who had an allowance, bank account, or investment when they were young saved more of their income as adults.

Based on the theory presented in this section, our study was guided by four central research questions: Among adolescents and young adults, who has a savings account? Are adolescents whose parents have a savings account for them more likely to have savings accounts as young adults than adolescents whose parents do not have a savings account for them? Are adolescents who have savings accounts more likely to have savings accounts in young adulthood than adolescents who do not have savings accounts? Are adolescents who have savings accounts more likely to have larger amounts saved in young adulthood than adolescents who do not have savings accounts?

\section{Method}

\section{Data}

This study used longitudinal data from the PSID and its supplements, specifically the Child Development Supplement (CDS) and the Transition into Adulthood supplement (TA). The PSID is a nationally representative longitudinal survey of U.S. individuals and families that began in 1968. The PSID collects data on characteristics such as employment, income, and assets. Our independent variables related to households and parents were taken from 1999, 2001, and 2003 PSID data.

The CDS was administered to 3,563 PSID respondents in 1997 to collect a wide range of data on parents who participated in the PSID and their children (birth to 12 years). Questions covered a range of developmental outcomes across the domains of health, psychological well-being, social relationships, cognitive development, achievement, motivation, and education. Follow-up surveys were administered in 2002 and 2007. For this study, independent variables for adolescents were taken from the 2002 CDS because that supplement represented the first data collection that included parents' savings for young people and young people's savings.

The TA supplement, administered in 2005 and 2007, measured outcomes for young adults who participated in earlier waves of the CDS and were no longer in high school. Of the 3,563 respondents from the $1997 \mathrm{CDS}$, 1,472 respondents were eligible to be interviewed for the TA in 2007, and 1,115 interviews were completed. The outcome variables for this study were taken from the 2007 TA.

The three datasets were linked using PSID, CDS, and TA map files that contained family and personal identification numbers. The linked datasets provided a rich opportunity for analyses in which data collected at one point in time (2002 or earlier) could be used to predict outcomes at a later point in time (2007), and stable background characteristics could be used as covariates. Because the PSID initially oversampled low-income families, both the descriptive and multivariate analyses were weighted using the last observed weight variable from the 2007 TA as recommended by the PSID/TA User Guide (Institute for Social Research, 2007). In addition to allowing the data to become representative of the general population, the 2007 TA weight variable compensated for attrition between the 1997 CDS and the 2007 TA. The weighted sample prior to propensity score analyses is referred to as the unadjusted sample in the analysis and results.

\section{Study Sample}

The sample in this study was restricted to Black and White adolescents given the small numbers of other racial groups in the TA. Further, only young people who were no longer in high school by 2007 (because they graduated, received a General Educational Development diploma [GED], or left school) were included in the sample. The unadjusted sample $(N=1,003)$ included 789 White and 207 Black adolescents. In 2002, the ages of 
adolescents in the sample ranged from 12 to 17 years $(M=15.96, S D=1.53)$. In the 2007 sample, young adults' ages ranged from 17 to 23 years $(M=19.92$, $S D=1.63$ ). Despite the apparent overlap in age ranges, data for adolescents came from the 2002 CDS sample and data for young adults came from the 2007 TA sample. In other words, adolescents in the 2002 CDS who were age 17 but still in high school were age 23 in the 2007 TA. Young adults who were 17 years old and were included in the 2007 TA had completed their high school education, received their GED, or left school. Descriptive statistics are presented in Tables 1 and 2.

\section{Variables of Interest}

Assets. Three types of assets were examined: net worth, parents' savings for adolescents, and adolescents' savings account in 2002.

Net worth. Net worth in the PSID was a continuous variable that summed separate household values for a business, checking or savings accounts, home equity, real estate, other property (e.g., personal vehicles, motor home, trailer, boat), stocks, and other cash assets (e.g., individual retirement accounts [IRAs] and annuities), and subtracted credit card and other debt. Net worth was averaged for 1999 and 2001; after 1999, net worth was inflated to 2001 price levels using the Consumer Price Index. Because net worth was skewed, we used the log transformation of net worth for the logistic regression analyses. Because some individuals had a negative value on the net worth variable, it was necessary to adjust these numbers so that the natural log of net worth could be calculated. All net worth values that were less than or equal to 0 were re-coded as 1 so that the natural log could be ascertained (e.g., Henretta \& Campbell, 1978; Orr, 2003). This adjustment affected approximately $14 \%$ of the sample.

Parents' savings for adolescents. Heads of households were asked in 2002 whether they (or another caregiver) had any money put aside for their adolescents in a bank account that was separate from other types of savings. These respondents were also asked whether they (or another caregiver) had any money put aside specifically for their adolescents' college or future schooling, separate from other types of savings they may have had for him or her. Responses to these two questions were combined to create a dichotomous variable indicating whether parents had separate savings for their adolescents.

Adolescents' savings account 2002. Adolescents were asked whether they had a savings or bank account in their name during 2002. The savings account 2002 variable separated adolescents into two categories: (a) those with an account in 2002, and (b) those without an account.

Outcome variables. The two outcome variables used in this study were (a) young adults' savings account in 2007 and (b) young adults' median savings amount in 2007.

Young adults' savings account 2007. Young adults were asked whether they had a savings or checking account in their name during 2007. The savings account 2007 variable separated young adults into two categories: (a) those with an account in 2007, and (b) those without an account.

Table 1

Descriptive Statistics for Adolescents' and Young Adults' Savings

\begin{tabular}{|c|c|c|c|}
\hline & $\begin{array}{c}\text { Unadjusted } \\
\frac{(N=1,003)}{\%}\end{array}$ & $\begin{array}{l}\text { Nearest Neighbor Match } \\
\qquad \frac{(N=446)}{\%}\end{array}$ & $\begin{array}{l}\text { ATT Weight } \\
\frac{(N=1,003)}{\%}\end{array}$ \\
\hline \multicolumn{4}{|l|}{ Adolescents' savings account } \\
\hline Have an account & 68 & 51 & 52 \\
\hline Do not have an account & 32 & 49 & 48 \\
\hline \multicolumn{4}{|l|}{ Young adults' savings account } \\
\hline Have an account & 84 & 81 & 84 \\
\hline Do not have an account & 16 & 19 & 16 \\
\hline \multicolumn{4}{|c|}{ Young adults' median savings amount } \\
\hline Savings above $\$ 500$ & 49 & 42 & 50 \\
\hline Savings below $\$ 500$ & 51 & 58 & 50 \\
\hline
\end{tabular}

Source: Weighted data from the Panel Study of Income Dynamics and its supplements. Data imputed using multiple imputations.

Note. ATT $=$ the average treatment effect for the treated using the weight of 1 for a treated case and $p /(1-p)$ for a non-treated case. 
FRIEDLINE, ELLIOTT, and NAM

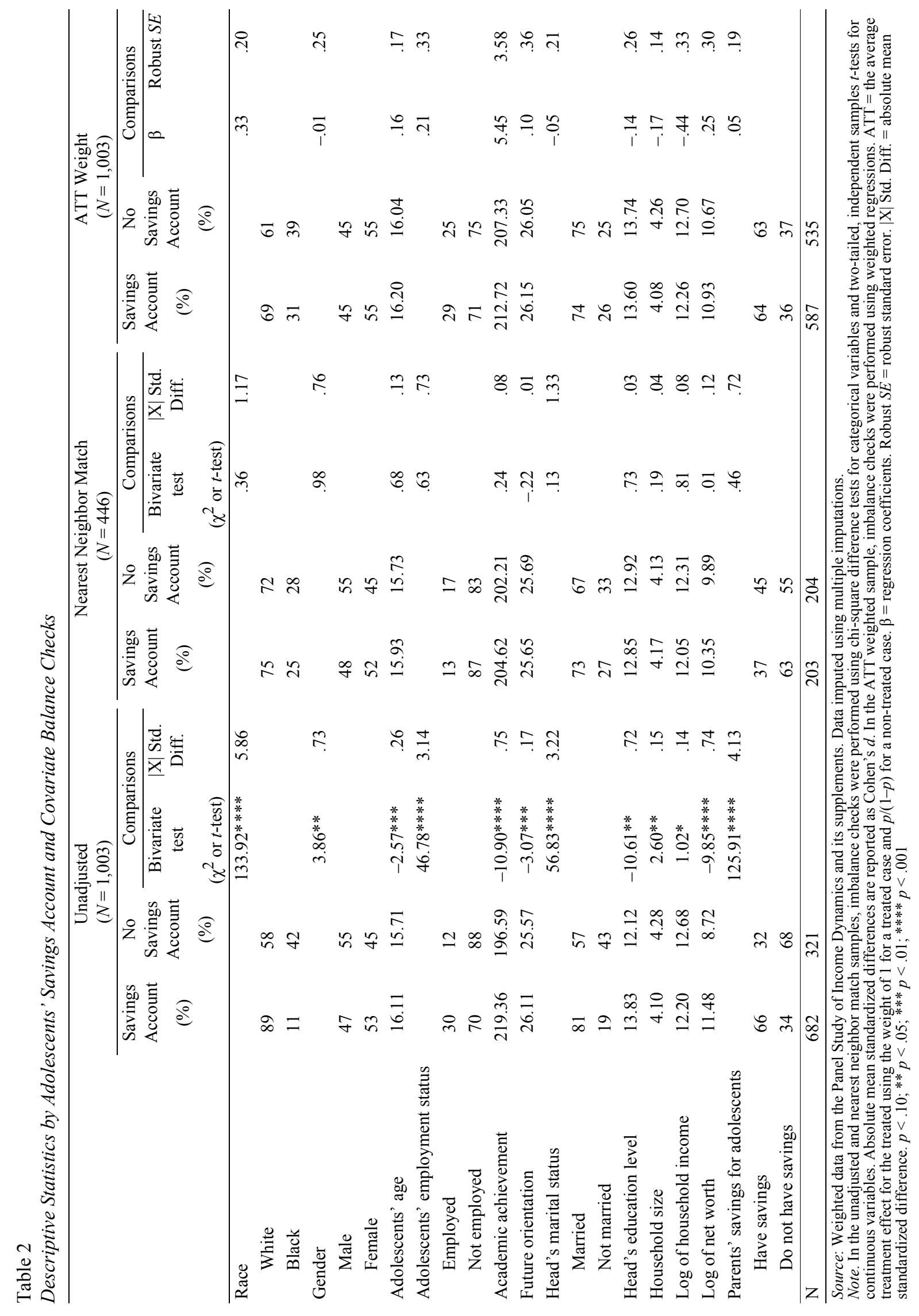


Young adults' median savings amount 2007. In the 2007 TA, savings amount was a continuous variable ranging from $\$ .01$ to $\$ 9,999,996$. The dependent variable was dichotomized at the median $(\$ 500)$ and used to create two categories: (a) above the median, and (b) below the median.

Control Variables. Several demographic control variables were used in the analysis, including adolescents' race, gender, and head of household's marital status and education level. Adolescents' race, a dichotomous variable (Black/White), was available from the 1997 wave of the PSID. Adolescents' gender was also a categorical variable (male/female), which was available from the 2002 wave of the CDS. Adolescents' age, available from the 2002 wave of the CDS, was a continuous variable and ranged from 12 to 17 years. Head of household's marital status (married/not married) was available from the 2001 wave of the PSID. Finally, head of household's education level was a continuous variable ranging from 1 to 16 and was available from the 2003 wave of the PSID; each number represents a year of completed schooling. For example, a head of household who had 12 years of education was considered to have graduated from high school. Additional controls included adolescents' employment status, academic achievement, future orientation, as well as the household's income and size.

Adolescents' employment status. Adolescents' employment status asked adolescents whether they worked for pay. Responses separated adolescents into two categories: (a) employed, and (b) not employed. This variable was available from the 2002 wave of the CDS.

Academic achievement. The variable for academic achievement was a continuous variable based on a composite score of Woodcock Johnson (WJ-R) Tests of Achievement, including Letter-Word Identification and Applied Problems. Letter-Word Identification and Applied Problems scores served as proxies for reading and math achievement, respectively. Adolescents' standardized scores were available from the 2002 wave of the CDS.

Future orientation index. The variable used for adolescents' future orientation index represented a composite score of seven questions from the 2002 wave of the CDS that asked adolescents, "What do you think are the chances you will..." (a) get divorced, (b) have enough money to support you and your family before age 30 , (c) graduate from a 2-year college or other vocational program, (d) graduate from a 4-year college, (e) have children, (f) get married, and (g) live past the age of 21?" Respondents chose among options including "(a) no chance, (b) some chance, (c) about 50-50, (d) pretty likely, and (e) it will happen." The scale was a reliable measure with a total Cronbach's alpha of .96 . Higher scores meant that adolescents were more orientated toward the future.

Household income. Household income was calculated by averaging household income for 1997 and 2001 with the 1997 income inflated to 2001 price levels using the Consumer Price Index. Because household income was skewed, the log transformation of household income was used in the logistic regression analyses.

Household size. Household size was shown with a continuous variable that ranged from 1 to 10 , representing the number of people living in a household. These data were available from the 2001 wave of the PSID.

\section{Analysis Plan}

This study examined predictors of two outcome variables: young adults' savings account and savings amount in 2007. There were several steps taken in the analysis plan to produce and analyze the results for these outcome variables. The first step was to analyze missing data to determine whether multiple imputation was appropriate for estimating and completing missing data. The second step was to conduct propensity score analyses for adolescents with savings accounts (i.e., treated cases) and adolescents without savings accounts (i.e., nontreated cases). The third step was to analyze the samples using logistic regression. The fourth and final step was to conduct Mantel-Haenszel tests (Mantel \& Haenszel, 1959) to examine the extent to which the results were sensitive to hidden bias, also referred to as unobserved heterogeneity. Data analysis steps were conducted using PASW Statistics (SPSS; version 18) and STATA (version 11). These steps are described in detail in the following paragraphs.

Missing data. Missing data among the variables might result in limitations regarding generalizability of the findings and model comparisons as well as reduced power (Rubin, 1976, 1987). Multiple imputation has been recognized as a preferred method for estimating and completing missing data (Little \& Rubin, 2002). This method assumes that missing data occur randomly. To accurately complete missing data, multiple imputations use information from the observed variables as well as the missing data. The Markov Chain Monte Carlo method was performed to create five completed, or imputed, datasets with no missing data (Saunders et al., 2006; Schafer \& Graham, 2002). The results were then pooled across the five imputed datasets to reduce bias in the estimations of parametric statistics (Saunders et al., 2006). The descriptive results, bivariate test statistics, beta coefficients, standard errors $(S E)$, odds 
ratios $(O R)$, and the $R^{2}$ values reported in the results were obtained from the averaged, pooled results across the five imputed datasets (Rubin, 1987; Saunders et al., 2006).

Propensity score analyses. The propensity score methods included both matching and weighting cases to create new samples and performing covariate balance checks (D’Agostino, 1998). These methods were undertaken for both outcome variables.

Following the estimation of the propensity scores, two methods of propensity score analysis were used, including nearest neighbor with caliper match and propensity score weighting. Matching typically reduces the sample size due to the inability to match all treated and nontreated observations (Guo, \& Fraser, 2010; Rosenbaum, 2002a, 2002b; Rosenbaum \& Rubin, 1985), which could cause a loss of a statistical power of the estimation of the treatment effect on outcome. Propensity score weighting was used as a non-sample-reducing correction to selection bias.

Propensity score estimation. Logistic regressions were performed to estimate the propensity scores (i.e., the predicted probability of having a savings account in 2002). Prior to estimating the propensity scores, bivariate tests were conducted to determine the covariates affecting selection bias. The results of these tests, which can be found in Table 2, revealed significant differences among all covariates. As a result, all covariates, including adolescents', head of household/parents', and household variables, were used to estimate the propensity scores (Rosenbaum, 2002b; Rosenbaum \& Rubin, 1983). According to the recommendations of Rosenbaum and Rubin (1984), covariates for the estimation of propensity scores were selected by running repeated stepwise logistic regressions. Covariates with group differences that were significant remained in the model to estimate the propensity score.

Nearest neighbor with caliper match. After estimating the propensity scores, nearest neighbor matching with caliper was performed (Cochran \& Rubin, 1973). Adolescents with (i.e., treated) and without (i.e., nontreated) savings accounts were randomly ordered. Then a treated adolescent was selected and matched with a nontreated adolescent using the closest propensity score within the region of caliper (Guo \& Fraser, 2010). The caliper size was equal to 0.25 times the standard deviation of the obtained propensity score. In this study, the caliper size ranged from .066 to .070 by each imputed dataset. The matched pair was not used in matching other pairs (i.e., matching without replacement). Propensity scores ranged from 0.097 to 0.96 . Among treated adolescents, less than $1 \%$ of the sample had propensity scores below 0.1 and none had propensity scores above 0.9. Among nontreated adolescents, less than 1\% of the sample had propensity scores below 0.1 , and approximately $2 \%$ had propensity scores above 0.9 . A common support region was imposed by trimming at $5 \%$ and removing treated adolescents whose propensity scores were lower than the minimum and removing nontreated adolescents whose scores were higher than the maximum propensity scores for nontreated adolescents. A visual inspection of the density distribution of propensity scores showed overlap after matching and trimming, indicating compliance with the common support condition.

\section{Average treatment-effect-for-the-treated (ATT)}

weight. The estimated propensity scores were also used to compute the average treatment-effect-for-the-treated (ATT; i.e., the effect when considering only adolescents in the treated group) sampling weight for each imputed dataset. The ATT weight was estimated as 1 for a treated adolescent and as $p /(1-p)$ for a nontreated adolescent where $p$ equals the propensity score. Propensity scores ranged from 0.03 to 0.98 . Among treated adolescents, approximately $1 \%$ of the sample had propensity scores below 0.1 and approximately $22 \%$ of the sample had propensity scores above 0.9. Among nontreated adolescents, less than $1 \%$ of the sample had propensity scores below 0.1 and approximately $9 \%$ of the sample had propensity scores above 0.9 . The propensity score distributions were slightly skewed. However, a visual inspection of the density distribution of propensity scores showed overlap after applying the ATT weight, indicating compliance with the common support condition.

Covariate balance checks. Balance checks were conducted to determine the ability of the propensity score analyses to balance relevant covariates. Given the potential selection bias evident among the covariates, balance checks were necessary to determine whether propensity score analyses adjusted for observed bias (Barth, Guo, \& McCrae, 2008; D’Agostino, 1998; Guo, Barth, \& Gibbons, 2006; Guo \& Fraser, 2010). For the sample matched using nearest neighbor with caliper, balance checks were performed using $\chi^{2}$ difference tests for categorical variables and two-tailed, independent samples $t$-tests for continuous variables. The absolute mean standardized differences were conducted using Cohen's $d$ (D'Agostino, 1998; Haviland, Nagin, \& Rosenbaum, 2007). For the sample using the ATT weight, balance checks were performed using weighted simple regression and weighted simple logistic regression (Guo \& Fraser, 2010). Weighted simple regressions were used when the covariate examined was a continuous variable and weighted simple logistic regression was used when the covariate examined was a categorical variable. Results of the weighted simple regressions and 
weighted logistic regressions are reported using regression coefficients and robust standard errors.

Logistic regression. Following the steps taken to balance the data, logistic regressions were used to predict young adults' savings account and median savings amount $( \pm \$ 500)$ in 2007. Results of the logistic regressions are presented in Tables 3 and 4 . Findings at significance levels of $p<.05$ and $p<.10$ are noted in the tables due to the exploratory nature of the study.

Sensitivity analyses for unobserved heterogeneity. Although propensity score analysis attempted to account for selection bias among observed covariates, bias could still be present because of unobserved covariates (Rosenbaum, 2002a, 2002b). This type of selection bias, also referred to as hidden bias or unobserved heterogeneity, may have been present because potentially important covariates could have been unknowingly omitted from the model. Mantel-Haenszel tests were conducted using the mhbounds procedure in STATA (version 11) to account for unobserved heterogeneity that may have affected selection into treated and nontreated groups (see Becker \& Caliendo, 2007). Mantel-Haenszel tests calculated the bounds to check sensitivity of the ATT weight results (Aakvik, 2001). The level of gamma $(\Gamma)$, a range of possible values attributable to unobserved heterogeneity, was set from 1 to 2 with an increment of 0.1 . A value of gamma close to 1 and significant indicates sensitivity to unobserved heterogeneity (Rosenbaum, 2005). Sensitivity analyses were conducted for both outcome variables.

\section{Results}

\section{Bivariate Results from Covariate Balance Checks}

Results from the balance checks are presented in Table 2. In the unadjusted sample, all covariates showed significant group differences between adolescents with savings accounts (i.e., treated) and adolescents without savings accounts (i.e., nontreated). In other words, savings accounts were significantly associated with adolescents when they were White $\left(\chi^{2}=133.92, p<.001\right)$, male $\left(\chi^{2}=3.86, p<.05\right)$, employed $\left(\chi^{2}=46.78\right.$, $p<.001)$, younger $(t=-2.57, p<.01)$, and had lower scores on measures of academic achievement $(t=-10.90$, $p<.001)$ and future orientation $(t=-3.07, p<.01)$. Further, savings accounts were significantly associated with adolescents when they lived in a household in which the head was married $\left(\chi^{2}=56.83, p<.001\right)$, had lower levels of education $(t=-10.61, p<.05)$, had savings on adolescents' behalf $\left(\chi^{2}=125.91, p<.001\right)$, and when the household had more members $(t=2.60, p<.05)$, higher income $(t=-1.02, p<.10)$, and lower net worth $(t=-9.85, p<.001)$.
Once conducting the nearest neighbor with caliper match and the ATT weight, group differences were no longer significant. This finding suggests that both nearest neighbor with caliper match and ATT weight were successful in reducing bias among observed covariates. The results are reported for the logistic regressions using the ATT weight given that the sample was not reduced and appeared more successfully balanced with propensity score weighting.

\section{Descriptive Results}

Tables 1 and 2 present the descriptive results for the unadjusted, nearest neighbor match, and ATT weight samples. In the unadjusted sample, $68 \%$ of adolescents had a savings account in 2002. The Black/White savings account gap was $78 \%$, with more Whites (89\%) having savings accounts during adolescence compared with Blacks $(11 \%)$. In aggregate, an estimated $84 \%$ of adolescents had a savings account in 2007. Almost an equal number of young adults had savings above $(49 \%)$ or below $(51 \%)$ the median $(\$ 500)$ in 2007. Sizable gaps between adolescents with and without savings accounts remained after applying the ATT weight. As shown in Table 2, our analyses indicated that the Black/White adolescents' savings account gap in 2002 was $38 \%$, with more Whites having savings accounts $(69 \%)$ as compared with Blacks (31\%). Gaps also existed by other demographic characteristics in the ATT weighted sample. Adolescents who had savings accounts scored more than five points higher on measures of academic achievement as compared with those who did not have savings accounts.

Among adolescents living in married households, $74 \%$ had savings accounts compared with $26 \%$ of adolescents living in nonmarried households, which was a gap of $48 \%$. Similarly, a gap of $28 \%$ existed between adolescents whose parents had savings on their behalf (64\%) compared with those whose parents did not have savings on their behalf (36\%).

\section{Predicting Savings in Young Adulthood}

The results from the logistic regression models that estimate the effects of adolescent, parent, and asset variables on savings account and savings amount in young adulthood are presented in Tables 3 and 4.

Savings account in 2007. The results predicting young adults' savings account in 2007 using the ATT weight are presented in Model 3. There was a significant prediction of young adults' savings account by the predictor variables in Model $3[\beta=-9.55, \mathrm{SE}=2.48$, $p<.0001$, Max-rescaled (Pseudo) $\left.R^{2}=.21\right]$. We found significant $(p<.05)$ predictors of young adults' savings account to include adolescents' race, future orientation, 
Table 3

Logistic Regression Predicting Young Adults' Savings Account in 2007

\begin{tabular}{|c|c|c|c|c|c|c|c|c|c|}
\hline & \multicolumn{3}{|c|}{$\begin{array}{c}\text { Model } 1 \\
\text { Unadjusted }\end{array}$} & \multicolumn{3}{|c|}{$\begin{array}{c}\text { Model 2 } \\
\text { Nearest Neighbor Match }\end{array}$} & \multicolumn{3}{|c|}{$\begin{array}{c}\text { Model } 3 \\
\text { ATT Weight }\end{array}$} \\
\hline & $\beta$ & SE & OR & $\beta$ & SE & OR & $\beta$ & SE & OR \\
\hline \multicolumn{10}{|l|}{ Base Model } \\
\hline White & .635 & $.277 * *$ & 1.89 & .611 & .454 & - & .828 & $.350 * *$ & 2.29 \\
\hline Male & .145 & .232 & - & -.098 & .391 & - & .222 & .392 & - \\
\hline Adolescents' age & .103 & .097 & - & .212 & .164 & - & .106 & .104 & - \\
\hline Adolescents are employed & .289 & .384 & - & .286 & 679 & - & .325 & .430 & - \\
\hline Academic achievement & .015 & $.006^{* *}$ & 1.02 & .013 & .009 & - & .014 & $.007 *$ & 1.01 \\
\hline Future orientation & .107 & $.037 * * *$ & 1.11 & .180 & $.057 * * *$ & 1.20 & .140 & $.043 * * *$ & 1.15 \\
\hline Married & .622 & $.273 * *$ & 1.86 & 1.011 & $.474 * *$ & 2.75 & .614 & $.333^{*}$ & 1.85 \\
\hline Head's education level & .162 & $.069 * *$ & 1.18 & .216 & .132 & - & .186 & $.072 * * *$ & 1.20 \\
\hline Household size & -.260 & $.082 * * *$ & .77 & -.181 & .175 & - & -.175 & .110 & - \\
\hline Log of household income & -.061 & $.030 * *$ & .94 & -.061 & .057 & - & -.041 & .032 & - \\
\hline \multicolumn{10}{|l|}{ Asset variables } \\
\hline Log of net worth & .042 & .027 & - & .083 & .055 & - & .044 & .031 & - \\
\hline Parents have savings for adolescents & .321 & .272 & - & .209 & .392 & - & .361 & .323 & - \\
\hline Adolescents' savings account in 2002 & .456 & $.223 * *$ & 1.58 & .653 & .468 & - & .594 & $.252 * *$ & 1.81 \\
\hline Maxed-rescaled (Pseudo) $R^{2}$ & & & .29 & & & .17 & & & .21 \\
\hline $\mathrm{N}$ & & & 1,003 & & & 446 & & & 1,003 \\
\hline
\end{tabular}

Table 4

Logistic Regression Predicting Young Adults' Median Savings Amount in 2007

\begin{tabular}{|c|c|c|c|c|c|c|c|c|c|}
\hline & \multicolumn{3}{|c|}{$\begin{array}{c}\text { Model } 4 \\
\text { Unadjusted }\end{array}$} & \multicolumn{3}{|c|}{$\begin{array}{c}\text { Model } 5 \\
\text { Nearest Neighbor Match }\end{array}$} & \multicolumn{3}{|c|}{$\begin{array}{c}\text { Model } 6 \\
\text { ATT Weight }\end{array}$} \\
\hline & $\beta$ & SE & OR & $\beta$ & SE & OR & $\beta$ & SE & OR \\
\hline \multicolumn{10}{|l|}{ Base Model } \\
\hline White & .596 & $.224 * * *$ & 1.82 & .935 & .336 & - & .509 & $.211 * *$ & 1.66 \\
\hline Male & -.050 & .225 & - & -.035 & .340 & - & .063 & .204 & 一 \\
\hline Adolescents' age & .031 & .072 & - & .031 & .126 & - & .042 & .066 & - \\
\hline Adolescents are employed & .365 & .288 & - & -.123 & .526 & - & .361 & .263 & - \\
\hline Academic achievement & .010 & $.004 * * *$ & 1.01 & .012 & $.006^{*}$ & 1.01 & .012 & $.004 * * *$ & 1.01 \\
\hline Future orientation & .053 & .041 & - & .093 & .060 & - & .055 & .037 & - \\
\hline Married & .100 & .253 & - & .300 & .426 & - & .231 & .226 & - \\
\hline Head's education level & .124 & $.055^{* *}$ & 1.13 & .171 & $.082 * *$ & 1.19 & .117 & $.051 * *$ & 1.12 \\
\hline Household size & .114 & .119 & - & -.005 & .172 & - & .001 & .091 & - \\
\hline Log of household income & -.041 & .036 & - & -.042 & .064 & - & -.050 & .033 & - \\
\hline \multicolumn{10}{|l|}{ Asset variables } \\
\hline Log of net worth & .082 & $.039 * *$ & 1.09 & .077 & .076 & - & .087 & $.037 * *$ & 1.09 \\
\hline Parents have savings for adolescents & .504 & $.217 * *$ & 1.65 & .386 & .378 & - & .371 & $.200 *$ & 1.45 \\
\hline Adolescents' savings account in 2002 & .287 & .219 & - & .623 & $.354^{*}$ & 1.87 & .252 & .197 & - \\
\hline Maxed-rescaled (Pseudo) $R^{2}$ & & & .17 & & & .15 & & & .16 \\
\hline $\mathrm{N}$ & & & 1,003 & & & 446 & & & 1,003 \\
\hline
\end{tabular}

Source: Weighted data from the Panel Study of Income Dynamics and its supplements. Data imputed using multiple imputations.

Note. $\beta=$ regression coefficients. $S E=$ standard error. $O R=$ odds ratio. ATT $=$ the average treatment effect for the treated using the weight of 1 for a treated case and $p /(1-p)$ for a nontreated case. In Model 5, confidence intervals cross zero for academic achievement and adolescents' savings variables $(p<.10)$. In Model 6 , confidence levels cross zero for parents' savings variable $(p<.10)$. ${ }^{*} p<.10 ; * * p<.05 ; * * * p<.01 ; * * * * p<.001$ 
and savings account as adolescents, and head of household's education level. Adolescents who were White were more than 2 times more likely to have a savings account in young adulthood $(O R=2.29, p=.02)$. For every one point increase in adolescents' future orientation, there was a $15 \%$ increase in the odds of having a savings account in young adulthood $(O R=1.15$, $p=.002$ ). For every one point increase in head of household's education level, there was a $20 \%$ increase in the odds of having a savings account in young adulthood $(O R=1.20, p=.01)$. Adolescents who had a savings account were almost 2 times more likely to have a savings account in young adulthood $(O R=1.81, p=.02)$.

Significant $(p<.10)$ predictors of young adults' savings account included adolescents' academic achievement and head of household's marital status. For every one point increase in adolescents' academic achievement, there was a $1 \%$ increase in the odds of having a savings account in young adulthood $(O R=1.01, p=.06)$. Adolescents whose heads of households were married were almost 2 times more likely to have a savings account in young adulthood $(O R=1.85$, $p=.07)$. However, $95 \%$ confidence intervals for adolescents' academic achievement and head of household's marital status crossed zero.

Saving account: Sensitivity of the results to unobserved heterogeneity. According to the results of the Mantel-Haenszel tests for young adults' savings account in 2007, the critical value of overestimating adolescents' savings account was somewhere below $1.85(p=.07)$ or $1.95(p=.04)$. This finding suggests that the results were moderately robust against unobserved heterogeneity that would cause an overestimation of the treatment effect up to 1.85 or 1.95 . In other words, the confidence intervals would include zero if an unobserved characteristic caused the odds ratio of adolescents' savings account to differ between those with and without savings accounts by 1.85 or 1.95 . Because adolescents who had savings accounts were 1.81 times more likely $(O R=1.81, p=02$; less than the critical value) to have savings accounts in young adulthood, the results appeared robust against unobserved heterogeneity.

Savings amount in 2007. The results predicting young adults' savings amount in 2007 using the ATT weight are presented in Model 6. There was a significant prediction of young adults' savings amount by the predictor variables in Model $6[\beta=-7.62, \mathrm{SE}=1.93$, $p<.0001$, Max-rescaled (Pseudo) $\left.R^{2}=.16\right]$. We found significant $(p<.05)$ predictors of young adults' savings account to include adolescents' race, academic achievement, head of household's education level, and household's log of net worth. White adolescents were more than 1.5 times more likely to have a savings account in young adulthood $(O R=1.66, p=.008)$. For every one point increase in adolescents' academic achievement, there was a $1 \%$ increase in the odds of having a savings account in young adulthood $(O R=1.01, p=.001)$. For every one point increase in head of household's education level, there was a $12 \%$ increase in the odds of having a savings account in young adulthood $(O R=1.12$, $p=.02$ ). For every one point increase in the $\log$ of household net worth, there was a $9 \%$ increase in the odds of accumulating savings above the median by young adulthood $(O R=1.09, p=.04)$. The effect of the $\log$ of household net worth on young adults' savings was also interpreted for every $\$ 1,000$ increase in household net worth by exponentiating the odds ratio to the $\log$ of $\$ 1,000$. For every $\$ 1,000$ increase in the log of net worth, there was almost a 1.5 point increase in the odds of accumulating savings above the median by young adulthood $(O R=1.30, p=.04)$.

Significant $(p<.10)$ predictors of young adults' savings account included parents' savings for adolescents. Adolescents whose parents had savings on their behalf were almost 1.5 times more likely to have a savings account in young adulthood $(O R=1.45, p=.07)$. However, $95 \%$ confidence intervals for parents' savings for adolescents crossed zero.

\section{Saving amount: Sensitivity of the results to} unobserved heterogeneity. According to the results of the Mantel-Haenszel tests for young adults' savings amount in 2007, the critical value of overestimating adolescents' savings amount was somewhere below $1.65(p=.098)$ or $1.75(p=.055)$. This finding suggests that the results were moderately robust against unobserved heterogeneity that would cause overestimation of the treatment effect up to 1.65 or 1.75 . In other words, the confidence intervals would include zero if an unobserved characteristic caused the odds ratio of adolescents' savings account to differ between those with and without savings accounts by 1.65 or 1.75 . Although adolescents' savings account was not significant in Model 6, adolescents who had savings accounts were 1.29 times more likely $(O R=1.29, p=19$; less than the critical value) to have savings above the median in young adulthood compared to those who did not have savings accounts as adolescents.

Summary. In sum, descriptive statistics revealed particularly large gaps in the percentage of adolescents with savings accounts by race, head of household's marital status, and parents' savings for adolescents. When multivariate analysis with ATT weight was used to predict having a savings account in young adulthood, adolescents' race, future orientation, and savings account as 
Table 5

Sensitivity Analyses for Unobserved Heterogeneity

\begin{tabular}{ccc}
\hline & $\begin{array}{c}\text { Savings Account in } \\
2007\end{array}$ & $\begin{array}{c}\text { Savings Amount in } \\
2007\end{array}$ \\
$\Gamma$ & $Q-\mathrm{MH}+$ & $Q-\mathrm{MH}+$ \\
\hline 1 & 1.25 & 1.07 \\
1.05 & 1.02 & .82 \\
1.15 & .58 & .36 \\
1.25 & .19 & -.07 \\
1.35 & -.03 & .26 \\
1.45 & .31 & .63 \\
1.55 & .63 & .97 \\
1.65 & .93 & $1.29^{*}$ \\
1.75 & 1.21 & $1.59^{* *}$ \\
1.85 & $1.48^{*}$ & $1.88^{* *}$ \\
1.95 & $1.73^{* *}$ & $2.15^{* *}$ \\
2 & $1.85^{* *}$ & $2.28^{* *}$ \\
\hline
\end{tabular}

Source: Weighted data from the Panel Study of Income Dynamics and its supplements. Data imputed using multiple imputations.

Note. $\Gamma=$ gamma. $Q-\mathrm{MH}+=$ Mantel-Haenszel statistic for

overestimation of treatment effect. ${ }^{*} p<.10 ; * * p<.05 ; * * * p<.01$; $* * * * p<.001$

well as the head of household's education level were significant predictors, controlling for all other factors. In regards to savings amount in young adulthood, the multivariate analysis revealed that variables including adolescents' race and academic achievement, head of household's education level, and household's log of net worth were significant predictors, controlling for all other factors.

Results for young adults' savings account and savings amount seemed moderately robust against potential hidden bias. In the case of savings account, the bounds under the assumption that we have over-estimated the treatment effect (i.e., $\mathrm{Q}+\mathrm{MH}$ ) revealed that at relatively high levels of $\Gamma$, the result become insignificant. Specifically, the result would not be significant at the $5 \%$ significance level any more with a value of $\Gamma=1.85$ $(p=.07)$. With $\Gamma=1.95$, the result would not be significant at the $10 \%$ significance level $(p=.04)$. Results were similar in the case of savings amount. The result would not be significant at the $5 \%$ significance level any more with a value of $\Gamma=1.65(p=.098)$. With $\Gamma=1.75$, the result would not be significant at the $10 \%$ significance level $(p=.055)$.

\section{Discussion}

Given the historically low rate of personal savings in the United States, building young people's financial capability is becoming increasingly important to the financial well-being of communities, families, and individuals as well as to the country as a whole. According to Johnson and Sherraden (2006), financial capability is developed by increasing young people's financial literacy (i.e., the knowledge, skills, confidence, and motivation needed to act) and by providing them with access to financial institutions. We suggest that an important way that families teach young people about the importance of saving is through modeling; that is, children learn to save by observing their parents' saving habits. In this study, we used parents' savings for adolescents as a proxy for parents' saving habits. Further, we suggest that if young adults are given access to savings accounts in adolescence, this access might help them establish a relationship with banking institutions that persists into young adulthood.

In the first part of this study, we examined who saves among adolescents and young adults. Previous studies have found that the majority of young people have savings (Elliott, 2009; Mandell, 2008). However, previous studies often did not disaggregate young people's savings by adolescent, parent, and asset characteristics. When the descriptive statistics were disaggregated by these characteristics among adolescents, we found that gaps in savings existed based on race, employment status, academic achievement, and parents' savings. These findings are similar to those from research on adults' savings (Lunt \& Livingstone,1991; GrinsteinWeiss \& Sherraden, 2004).

To date, little research has predicted young adults' savings using household asset variables. In this study, we included both net worth and parents' savings for adolescents. We found no evidence that adolescents whose parents have savings for them were more likely to have savings accounts as young adults as compared with their counterparts. This finding is inconsistent with previous findings. For example, Pritchard et al. (1989) used a sample of high-school seniors and found a significant relationship between parents' savings and young people's savings. Methodological differences may explain inconsistent findings among studies. Although we used logistic regressions with propensity score weighting to control for various factors, Pritchard et al. (1989) used bivariate statistics (chi-square and Somer's d). Therefore, the significant finding by Pritchard et al. (1989) may be spurious. Alternatively, differences in findings may result from the use of different samples. The Pritchard et al. (1989) study, which used cross-sectional data, included only high-school seniors who were 
employed. In contrast, our sample included a wider age range of young people (12 to 17 years old in 2002 and 17 to 23 years old in 2007), and included both employed and unemployed young people. We found no relationship between household net worth and having a savings account in young adulthood. Further, we found no studies that have examined the relationship between household net worth and young people's savings.

We also examined the issue of inclusion as it related to young people's financial capability. Adolescents' savings account was used as a proxy for the likelihood of inclusion in young adulthood. Results provided some support for the proposition that adolescents who had savings accounts were more likely to have savings accounts as young adults, even after adjusting for all other variables. Because many studies that investigate young people's savings are cross-sectional or are limited to samples with younger age groups (e.g., Berti \& Bombi, 1981b; Otto et al., 2006; Pritchard et al., 1989; Webley et al., 1991; Webley \& Nyhus, 2006), no similar comparisons exist in the research on young people.

Several other variables significantly predicted young adults' savings account in 2007. Adolescents' race and future orientation and the head of household's education level were positive and significant predictors of young adults' savings account. Adolescents' academic achievement and head of household's marital status were also significant $(p<.10)$; however, the confidence intervals crossed zero and the results regarding adolescents' academic achievement and head of household's marital status should be interpreted with caution. Few studies have examined the association between race and having a savings account. For instance, Pritchard and colleagues (1989) used factor analysis and chi-square difference tests to analyze a cross-sectional sample of 1,619 employed high-school seniors, and found that being White was positively and significantly related being a saver as compared with being Black. An unpublished, cross-sectional study by Mandell (2005) used a sample of 4,074 high school seniors and found that Whites were 1.68 times more likely to have savings accounts than Blacks. However, Mandell's study provided very little information about the sample and methodology and controls only for a dichotomous measure of household income and home ownership. More research is needed that examines the relationship between adolescents' race and their savings later in life.

Future orientation was also found to be a significant predictor of young adults' savings, which is consistent with theory (Beverly et al., 2008) and previous research (Pritchard et al., 1989; Webley \& Nyhus, 2006). Findings regarding young adults' savings account were mod- erately robust against potential hidden bias, suggesting that the results of the treatment effect were not overestimated.

Moreover, we examined predictors of young adults' savings amount. Findings suggest that adolescents' race and academic achievement, head of household's education level, and household net worth are all positive, statistically significant predictors of young adults' savings amount. Parents' savings on adolescents' behalf was also significant $(p<.10)$; however, the confidence intervals crossed zero and the results regarding parents' savings should be interpreted with caution. We found no previous research examining the relationships between household net worth and young adults' savings amount. However, two studies have examined the relationship between parents' savings and, more generally, young people's amount saved.

Mason et al. (2010) found that parents' savings was not associated with young people's savings amount. However, these researchers did not examine parents' savings that were designated for young people's use. Instead, Mason et al. (2010) used a general savings variable where savings could be used for any purpose. Moreover, the mean age of young people in the Mason et al. study sample was approximately 7 years old as compared to a mean age of approximately 20 years in our study (at the time savings amount was measured). We speculate that parental role modeling of savings habits may not become important until children are older and begin to set long-term goals. Research on young people and savings has suggested that around age 6 years, young people are thinking about saving for short-term goals, and it is not until around age 12 years old that young people begin to think about saving for long-term goals (Sonuga-Barke \& Webley, 1993; Webley et al., 1991). It may be that parental role modeling is more important once young people gain the capability for thinking about saving for long-term goals. In line with this idea, Webley and Nyhus (2006) also found that parents' savings were associated with savings amounts of young adults (i.e., ages 16 to 21 years). However, Webley and Nyhus used bivariate analysis to test the relationship (Pearson correlation), leaving open the question of whether the relationship is spurious. Further, neither the current study nor Webley and Nyhus's study followed a group of young people younger than 12 years through young adulthood to test whether parents' savings was significant prior to and after the age of 12 . Given these limitations and the modest findings regarding the relationship between parents' savings and young adults' savings amount in this study, more research is needed to test parental role modeling of saving habits on young people's saving habits, including whether parents' 
savings have more influence on young people's saving habits before or after 12 years of age.

In addition to assets, adolescents' race and academic achievement as well as head of household's education level were statistically significant in this study. Similarly, Mason et al. (2010) found that young people's race (being non-Latino Black and Native American was negatively associated with amount saved whereas Asian race was positively associated with amount saved as compared with being non-Latino White) and head of household's education at a bachelor's degree or higher were significantly related to the amount saved. Mason et al. (2010) did not include a measure of young people's academic achievement. Findings regarding young adults' savings amount were moderately robust against potential hidden bias, suggesting that the results of the treatment effect were not overestimated.

Notably, household income was not significant in our current study. Similarly, Mason et al. (2010) found household income was not significant. However, Mason et al. (2010) used a monthly household income variable whereas we used an annual measure of household income that was averaged over 2 years. In contrast, Webley and Nyhus (2006) found that household income was significantly related to the amount of young people's savings. However, as previously stated, Webley and Nyhus's finding was based on bivariate analysis (Pearson correlation), and thus does little to rule out the possibility of a spurious relationship. It appears that when other factors are considered, household income may not be a significant predictor of the amount saved by young adults.

\section{Limitations}

The results of this study should be considered in light of several limitations. A limitation is the average age of adolescents and young adults. The mean age of adolescents was 16 years old, which is late in the adolescent trajectory and does not show savings exclusively for adolescents closer to the ages of 12 to 15 when young people begin to develop and broaden complex saving strategies. However, there were 164 young people ages 12 to 15 years old in this study, suggesting that this age group was still well-represented within the dataset. In addition, the mean age of young adults was 20 years, which is still somewhat early in the transition between adolescence and young adulthood. Young adults at age 20 may not have established themselves as completely independent from their parents' households, and some research suggests that the actual age of financial independence occurs substantially later. For example, in 2000 , only $50 \%$ of males and $61 \%$ of females were considered their own heads of households by age
26 , whereas, $71 \%$ of males and $79 \%$ of females had established themselves as heads of households by age 30 (Bell, Burtless, Gornick, \& Smeeding, 2007). Research should examine savings for young adults closer to the age of financial independence.

Findings of this study must also be considered in light of several methodological limitations. The results of the nearest neighbor with caliper match appeared less successful in producing reliable results as compared with the ATT weight. The differences in results could be due to the reduction in sample size that takes place when matching treated and nontreated adolescents (D'Agostino, 1998; Dehejia \& Wahba, 2002). This is a plausible explanation given that all covariates were used to perform the matching operation, thus limiting the available matches. In this case, the sample size for the nearest neighbor with caliper was 446 .

One benefit of using the ATT weight was that there was not a reduction in sample size because the propensity scores were used as weights to balance the sample. However, propensity score weighting may increase random error in the estimates due to endogeneity and specification of the propensity score estimation equation (Freedman \& Berk, 2008). All covariates were used in the specification of the propensity score estimation and logistic regression equations, which is not commonly advised (Freedman \& Berk, 2008). In some cases, propensity score weighting has been found to exaggerate endogeneity (Freedman \& Berk, 2008). Moreover, adolescents' savings account may be endogeneous if assignment into the treated and nontreated groups correlated with unobserved covariates that impact their savings in young adulthood.

We attempted to explore the extent to which results were endogeneous by examining unobserved heterogeneity between adolescents with and without savings accounts. Sensitivity analyses were conducted on young adults' savings account and savings amount. The sensitivity analyses suggest that the results of this study were fairly robust against unobserved heterogeneity. However, relatively few studies have examined predictors of adolescents' or young adults' savings, and it is likely that we do not yet know all of the relevant or important predictors of young adults' savings. As a result, unobserved heterogeneity may have been introduced by our unknowingly omitting relevant or important predictors from this study. More research is needed that predicts adolescents' and young adults' savings.

\section{Implications}

Descriptive findings suggest that adolescents' and young adults' access to savings institutions occurs 
disproportionately based on demographic characteristics. This finding is counter to the story portrayed by aggregate data, which shows that most young people have savings. At first glance, aggregate data indicate that $68 \%$ of adolescents and $84 \%$ of young adults have savings in the unadjusted sample. Policy makers presented with aggregate data may overlook differences along class lines and erroneously conclude that savings programs are not needed. For example, disaggregate data in the unadjusted sample indicate that only $11 \%$ of adolescents who are Black have savings as compared with $89 \%$ of White adolescents. Similarly, adolescents also have savings accounts more often when the head of household is married, has higher levels of education, and has savings on adolescents' behalf and the household has greater amounts of net worth. Sizeable gaps in adolescents' savings account remain even after adjusting the sample with the ATT weight. Therefore, we suggest that disaggregating data when examining young people's savings is an important implication for future policy and research.

In multivariate analyses, adolescents' savings accounts significantly predict having savings accounts in young adulthood. An implication of this finding is that having savings accounts in adolescence may be a way to help increase inclusion in financial institutions in young adulthood. Having savings accounts in adolescence becomes an even more important topic when we realize that large gaps in adolescents' savings may not only lead to less access to financial institutions and poorer saving habits as young adults, but also lead to poorer life chances. For example, research has suggested that adolescents' savings is an important predictor of adolescents' academic attainment (Elliott, 2009; Elliott, Jung, et al., 2010; Elliott, Zhan, Sherraden, \& Friedline, 2010). Further, educational attainment is an important predictor of the amount of income young people earn over the course of their lifetime (Baum \& Ma, 2007) and the amount of assets they earn (Haurin, Hendershott, \& Wachter, 1996). This relationship implies that young people's savings programs may not only increase savings in young adulthood but also play an important part in determining the kinds of life chances available to them.

Another implication of this study is that parents may play an important role in modeling good saving habits to their children, particularly with respect to the amount saved in young adulthood. Although more research is needed to confirm this relationship, policy makers might consider programs such as Individual Development Accounts (IDAs) as a potential way to build assets among low-income households and reverse savings inequalities that exist along class lines. IDAs are matched-savings accounts that can be used for a particular purpose (e.g., buying a home, paying for education, or starting a business). Given this suggestion, even though the life-cycle hypothesis downplays the importance of young people's savings, this study provides additional evidence for why more research is needed that focuses on the importance of savings at an early age.

\section{Conclusion}

Despite the trend away from saving in United States, many would argue that saving remains an important method for attaining long-term goals or as a way to provide a safety net when income varies. In contrast to life-cycle hypothesis theory, this study suggests that savings beginning at a young age may lead to an increased likelihood of savings later in life and having more money saved. In essence, once a penny is saved in adolescence, it apparently continues to be saved in young adulthood.

\section{Author Note}

Terri Friedline is a $\mathrm{PhD}$ student at the University of Pittsburgh School of Social Work.

William Elliott is an assistant professor at the University of Pittsburgh, School of Social Work: wie1@pitt.edu

Ilsung Nam is a $\mathrm{PhD}$ student at the University of Pittsburgh's School of Social Work: iln1@pitt.edu

Correspondence regarding this article should be addressed to Terri Friedline at tlf13@pitt.edu

\section{References}

Aakvik, A. (2001). Bounding a matching estimator: The case of a Norwegian training program. Oxford Bulletin of Economics and Statistics, 63(1), 115143. doi:10.1111/1468-0084.00211

Alessie, R., \& Teppa, F. (2010). Saving and habit formation: Evidence from Dutch panel data.

Empirical Economics, 38(2), 385-407. doi:10.1007/s00181-009-0272-z

American Bankers Association. (2009). Teach children to save: Building a generation of savers. Retrieved from http://www.aba.com/ABAEF/tcts.htm

Barth, R., Guo, S., \& McCrae, J. (2008). Propensity score matching strategies for evaluating the success of child and family service programs. Research on Social Work Practice, 18(3), 212-222.doi:10.1177/ $\underline{1049731507307791}$ 
Becker, S. O., \& Caliendo, M. (2007). mhbounds: Sensitivity analysis for average treatment effects (DIW Discussion Paper No. 659). Berlin, Germany: German Institute for Economic Research. Retrieved from http://www.diw.de/documents/publikationen/ 73/diw 01.c.55697.de/dp659.pdf

Bell, L., Burtless, G., Gornick, J., \& Smeeding, T. (2007). Failure to launch: Cross-national trends in the transition to economic independence. In S. Danziger \& C. Rouse (Eds.), The price of independence: The economics of early adulthood. New York, NY: Russell Sage Foundation. http://www.transad.pop.upenn.edu/publications/ priceofindependence.htm

Bernheim, B. D., \& Garrett, D. M. (1996). The determinants and consequences of financial education in the workplace: Education from a survey of households (Working Paper No. 5667). Cambridge, MA: National Bureau of Economic Research. http://www.nber.org/papers/w5667

Bernheim, B. D., Garrett, D. M., \& Maki, D. M. (2001). Education and saving: The long-term effects of high school financial curriculum mandates. Journal of Public Economics, 80(3), 435-465. doi:10.1016/ $\underline{\mathrm{S} 0047-2727(00) 00120-1}$

Bernheim, B. D., \& Scholz, J. K. (1993). Private saving and public policy. Tax Policy and the Economy, 7(3), 73-110. Retrieved from http://www.jstor.org/ pss/20060630

Berti, A. E., \& Bombi, A. S. (1981a). The child's construction of economics (G. Duveen, Trans.). Cambridge, UK: Cambridge University Press. http://dpss.psy.unipd.it/files/berti2.php

Berti, A. E., \& Bombi, A. S. (1981b). The development of the concept of money and its value: A longitudinal study. Child Development, 52(4), 1179-1182. doi:10.2307/1129504

Beutler, I., \& Dickson, L. (2008). Consumer economic socialization. In J. J. Xiao (Ed.), Handbook of consumer finance research. New York, NY: Springer.

Beverly, S. (1997). How can the poor save? Theory and evidence on saving in low-income households (CSD Working Paper No. 97-3). St. Louis, MO: Washington University, Center for Social Development. Retrieved from http://csd.wustl.edu/ Publications/Documents/10.HowCanThePoorSave.pdf
Beverly, S., \& Sherraden, M. (1999). Institutional determinants of saving: Implications for lowincome households and public policy. Journal of Socio-Economics, 28(4), 457-473. doi:10.1016/ $\underline{\mathrm{S} 1053-5357(99) 00046-3}$

Beverly, S., Sherraden, M., Cramer, R., Williams Shanks, T., Nam, Y., \& Zhan, M. (2008). Determinants of asset holdings. In S-M. McKernan \& M. Sherraden (Eds.), Asset building and lowincome families. Washington, DC: Urban Institute Press. http://www.urban.org/UploadedPDF/ 411650 asset_building.pdf

Bosworth, B. (2006). United States savings in a global context. Washington, DC: Brookings Institution. http://www.brookings.edu/testimony/2006/ 0406macroeconomics bosworth.aspx

Bureau of Economic Analysis. (2009). Personal saving rate. Retrieved from http://www.bea.gov/briefrm/ saving.htm

Bush, G. W. (2004). America's ownership society: Expanding opportunities. Retrieved from http://georgewbush-whitehouse.archives.gov/news/ releases/2004/08/20040809-9.html

Carr Steelman, L., \& Powell, B. (1989). Acquiring capital for college: The constraints of family configuration. American Sociological Review, 54(5), 844-855. doi:10.2307/2117758

Carr Steelman, L., \& Powell, B. (1991). Sponsoring the next generation: Parental willingness to pay for higher education. American Journal of Sociology, 96(6), 1505-1529. doi:10.1086/229695

Cline, S. (2005, April 1). Denver children learn financial basics at Young Americans Center. Colorado Springs Business Journal. Retrieved from http://findarticles.com/p/articles/mi qn4190/ is 20050401/ai_n13492639/

Cochran, W. G., \& Rubin, D. B. (1973). Controlling bias in observational studies: A review. Sankya: The Indian Journal of Statistics, Series A, 35, 417446. http://www.jstor.org/stable/25049893

Conley, D. (1999). Being Black, living in the red. Berkeley: University of California Press.

Council for Economic Education. (2010). Program highlights. Retrieved from http://www.councilforeconed.org/ 
Cramer, R., Hueslman, M., King, J., Lopez-Fernandini, A., \& Newville, D. (2010). The assets report 2010: An assessment of president Obama's 2011 budget and the changing policy landscape for asset building opportunities. Washington, DC: New American Foundation. http://www.newamerica.net/ publications/policy/the assets report 2010

Cruce, A. (2001). A history of Progressive Era school savings banking, 1870 to 1930 (Working Paper No. 01-3). George Warren Brown School of Social Work, Center for Social Development. http://csd.wustl.edu/Publications/Documents/ 70.AHistoryOfProgressiveEraSchool.pdf

Cruce, A. (2002). School-based savings programs, 1930 to 2002 (Working Paper No. 02-7). George Warren Brown School of Social Work, Center for Social Development. http://csd.wustl.edu/Publications/ Documents/wp02-7.pdf

D’Agostino, R. (1998). Tutorial in biostatistics: Propensity score methods for bias reduction in the comparison of a treatment to a non-randomized control group. Statistics in Medicine, 17(19), 22652281. doi:10.1002/(SICI)10970258(19981015)17:19<2265::AID$\underline{\text { SIM918>3.0.CO;2-B }}$

Dehejia, R. H., \& Wahba, S. (2002). Propensity score matching methods for non-experimental casual studies. Review of Economics and Statistics, 84(1), 151-161. http://www.nber.org/ rdehejia/papers/ matching.pdf

Deaton, A. (1991). Saving and liquidity constraints. Econometrica, 59(5), 1221-1248. doi:10.2307/ $\underline{2938366}$

Diamond, P. A., \& Hausman, J. A. (1984). Individual retirement and savings behavior. Journal of Public Economics, 23, 81-114. doi:10.1016/0047$\underline{2727(84) 90068-9}$

Elliott, W. (2009). Children's college aspirations and expectations: The potential role of children's development accounts (CDAs). Children and Youth Services Review, 31(2), 274-283. doi:10.1016/ j.childyouth.2008.07.020

Elliott, W., Jung, H., \& Friedline, T. (2010). Math achievement and children's savings: Implications for Child Development Accounts. Journal of Family and Economic Issues, 31(2), 171-184. doi:10.1007/s10834-010-9185-4
Elliott, W., Zhan, M., Sherraden, M., \& Friedline, T. (2010). A review of research on savings, assets, and young people's educational outcomes. Pittsburgh, PA: University of Pittsburgh, Center on Race and Social Problems.

Engel, R., \& Schutt, R. (2005). The practice of research in social work. Thousand Oaks, CA: Sage.

Frederick, S., Loewenstein, G., \& O’Donoghue, T. (2003). Time discounting and time preference: A critical review. Journal of Economic Literature, 40(2), 351-401. doi:10.1257/002205102320161311

Freedman, D. A., \& Berk, R. A. (2008). Weighting regressions by propensity scores. Evaluation Review, 32(4), 392-409. doi:10.1177/ $\underline{0193841 X 08317586}$

Furnham, A. (1985). Why do people save? Attitudes to, and habits of, saving money in Britain. Journal of Applied Social Psychology, 15(5), 354-373. doi:10.1111/j.1559-1816.1985.tb00912.x

Furnham, A. (1999). The saving and spending habits of young people. Journal of Economic Psychology, 20(6), 677-697. doi:10.1016/S01674870(99)00030-6

Grinstein-Weiss, M., \& Sherraden, M. (2004). Racial differences in performance in a matched savings program. Journal of Income Distribution, 13(3/4), 98-111. http://www.jid-online.org/

Grinstein-Weiss, M., Yeo, Y. H., Despard, M. R., Casalotti, A. \& Zhan, M. (2010). Does prior banking experience matter? Differences of the banked and unbanked in Individual Development Accounts. Journal of Family and Economic Issues, 31(2), 212-227. doi:10.1007/s10834-010-9184-5

Guo, S., Barth, R., \& Gibbons, C. (2006). Propensity score matching strategies for evaluating substance abuse services for child welfare clients. Children and Youth Services Review, 28(4), 357-383. doi:10.1016/j.childyouth.2005.04.012

Guo, S., \& Fraser, M. (2010). Propensity score analysis: Statistical methods and applications. Los Angeles, CA: Sage.

Harrah, J., \& Friedman, M. (1990). Economic socialization in children in a Midwestern American community. Journal of Economic Psychology, 11, 495-513. doi:10.1016/0167-4870(90)90031-4

Harrod, R. F. (1948). Towards a dynamic economics. London, UK: Macmillan. http://www.questia.com/ PM.qst? $\mathrm{a}=\mathrm{o} \& \mathrm{~d}=211447$ 
Haurin, D. R., Hendershott, P. H., \& Wachter, S. M. (1996). Wealth accumulation and housing choices of young households: An exploratory investigation. Journal of Housing Research, 7(1), 33-57.

Haviland, A., Nagin, D. S., \& Rosenbaum, P. R. (2007). Combining propensity score matching and groupbased trajectory analysis in an observational study. Psychological Methods, 12(3), 247-267. doi:10.1037/1082-989X.12.3.247

Henretta, J. C., \& Campbell, R. T. (1978). Net worth as an aspect of status. American Journal of Sociology, 83, 1204-1223. doi:10.1086/226679

Hogarth, J., Anguelov, C., \& Lee, J. (2003). Why households don't have checking accounts. Economic Development Quarterly, 17(1), 75-94. doi:10.1177/0891242402239199

Hogarth, J., Anguelov, C., \& Lee, J. (2005). Who has a bank account? Exploring changes over time, 19892001. Journal of Family and Economic Issues, 26(1), 7-30. doi:10.1007/s10834-004-1410-6

Howlett, E., Kees, J., \& Kemp, E. (2008). The role of self-regulation, future orientation, and financial knowledge in long-term financial decisions. Journal of Consumer Affairs, 42(2), 223-242. doi:10.1111/j.1745-6606.2008.00106.x

Institute for Social Research. (2007). The Child Development Supplement Transition Into Adulthood Study 2007: User guide. Retrieved from http://psidonline.isr.umich.edu/CDS/ TA07 UserGuide.pdf

Jahoda, G. (1981). The development of thinking about economic institutions: The bank. Cahiers de Psychologie Cognitive/Current Psychology of Cognition, 1, 55-73.

Jahoda, G., \& France, A. (1979). The construction of economic reality by some Glaswegian children. European Journal of Social Psychology, 9, 115127. doi:10.1002/ejsp.2420090202

Johnson, E., \& Sherraden, M. S. (2006). From financial literacy to financial capability among youth. Journal of Sociology and Social Welfare, 34(3), 119-145. http://csd.wustl.edu/Publications/ Documents/WP06-11.pdf

Junior Achievement. (2009). Educating students worldwide. Retrieved from http://www.ja.org/

Katona, G. (1975). Psychological economics. New York, NY: Elsevier.
Kotlikoff, L. J. \& Bernheim, B. D. (2001). Household financial planning and financial

Literacy: The need for new tools. In L. J. Kotlikoff (Ed), Essays on Saving, Bequests, Altruism, and LifeCycle Planning (pp. 427-478). Cambridge, MA: The MIT Press.

Kotlikoff, L. J., Spivak, A., \& Summers, L. H. (1982). The adequacy of savings. American Economic Review, 72(5), 1056-1069. Retrieved from http://www.jstor.org/stable/i304610

Lawrence, E. C. (1991). Poverty and the rate of time preference: Evidence from panel data. Journal of Political Economy, 99(1), 54-77. doi:10.1086/ 261740

Leiser, D. (1983). Children's conception of economics The constitution of a cognitive domain. Journal of Economic Psychology, 4(4), 297-317. doi:10.1016/ $\underline{0167-4870(83) 90036-3}$

Leiser, D., \& Ganin, M. (1996). Economic participation and economic socialization. In P. K. Lunt \& A. Furnham (Eds.), Economic socialization: The economic beliefs and behaviors of young people (pp. 93-109). Cheltenham, UK: Edward Elgar.

Leiser, D., Sevón, G., \& Lévy, D. (1990). Children's economic socialization: Summarizing the crosscultural comparison of ten countries. Journal of Economic Psychology, 11, 591-614. doi:10.1016/ 0167-4870(90)90038-B

Little, R.J.A., \& Rubin, D. B. (2002). Statistical analysis with missing data (2nd ed.). New York, NY: John Wiley \& Sons.

Lunt, P. K., \& Livingstone, S. M. (1991). Psychological, social, and economic determinants of saving: Comparing recurrent and total savings. Journal of Economic Psychology, 12, 621-641. doi:10.1016/ $\underline{0167-4870(91) 90003-C}$

Mandell, L. (2005). Financial literacy: Does it matter? Unpublished manuscript, Department of Finance and Managerial Economics, State University of New York, Buffalo, NY. Retrieved from http://www.jumpstart.org

Mandell, L. (2008). The financial literacy of young American adults: Results of the 2008 national Jump\$tart Coalition survey of high school seniors and college students. Washington, DC: University of Washington and the Aspen Institute. http://www.jumpstart.org/assets/files/ 2008SurveyBook.pdf 
Mantel, N., \& Haenszel, W. (1959). Statistical aspects of the analysis of data from retrospective studies of disease. Journal of the National Cancer Institute, 22, 719-748.

Masa, R. (2009). Innovations in youth saving and asset building around the world (CSD Publication No. 09-52). St. Louis, MO: Washington University, Center for Social Development. http://csd.wustl.edu/Publications/Documents/ RB09-52.pdf

Mason, L. R., Nam, Y., Clancy, M., Loke, V., \& Kim, Y. (2009). SEED account monitoring research: Participants, savings, and accumulation (CSD Research Report 09-05). St. Louis, MO: Washington University, Center for Social Development. http://csd.wustl.edu/Publications/ Documents/RP09-05.pdf

Mason, L. R., Nam, Y., Clancy, M., Kim, Y., \& Loke, V. (2010). Child development accounts and saving for children's future: Do financial incentives matter? Children and Youth Services Review, 32(11), 1570-1576. doi:10.1016/ j.childyouth.2010.04.007

McNeal, J. U. (1987). Children as consumers: Insights and implications. Lexington, MA: Lexington Books.

Miller, D. (1995). Acknowledging consumption: A review of new studies. New York, NY: Routledge.

Modigliani, F., \& Brumberg, R. (1954). Utility analysis and the consumption function: An interpretation of cross-section data. In K. K. Kurihara (Ed.), PostKeynesian economics (pp. 388-436). New Brunswick, NJ: Rutgers University Press.

Nyhus, E., \& Webley, P. (2006). Discounting, selfcontrol, and saving. In M. Altman (Ed.), Handbook of contemporary behavioral economics: Foundations and developments. Armonk, NY: M.E. Sharpe.

Organisation for Economic Co-Operation and Development. (2009). Country statistical profiles 2009: United States. Retrieved from http:// stats.oecd.org/Index.aspx?DataSetCode=CSP2009

Orr, A. (2003). Black-White differences in achievement: The importance of wealth. Sociology of Education, 76(4), 281-304. doi:10.2307/ $\underline{1519867}$
Otto, A., Schots, P., Westerman, J., \& Webley, P. (2006). Children's use of saving strategies: An experimental approach. Journal of Economic Psychology, 27, 57-72. doi:10.1016/ j.joep.2005.06.013

Pritchard, M. E., Myers, B. K., \& Cassidy, D. (1989). Factors associated with adolescent saving and spending patterns. Adolescence, 24(95), 711-723. PMid:2801291

Rosenbaum, P. R. (2002a). Covariance adjustment in randomized experiments and observational studies. Statistical Science, 17(3), 286-304. doi:10.1214/ss/ $\underline{1042727942}$

Rosenbaum, P. R. (2002b). Observational studies. New York, NY: Springer.

Rosenbaum, P. R. (2005). Sensitivity analysis in observational studies. In B. S. Everitt \& D. C. Howell (Eds.), Encyclopedia of statistics in behavioral science (pp. 1809-1814). New York, NY: Wiley.

Rosenbaum, P. R., \& Rubin, D. B. (1983). The central role of the propensity score in observational studies for causal effects. Biometrika, 70(1), 41-55. doi: $10.2307 / 2335942$

Rosenbaum, P. R., \& Rubin, D. B. (1984). Reducing bias in observational studies using subclassification on the propensity score. Journal of the American Statistical Association, 79(387), 516524. doi: $10.2307 / 2288398$

Rosenbaum, P. R., \& Rubin, D. B. (1985). Constructing a control group using multivariate matched sampling methods that incorporate the propensity score. American Statistician, 39(1), 33-38. doi: $10.2307 / 2683903$

Rubin, D. B. (1976). Inference and missing data. Biometrika, 63(3), 581-592. doi:10.2307/2335739

Rubin, D. B. (1987). Multiple imputation for nonresponse in surveys. New York, NY: John Wiley \& Sons.

Saunders, J., Marrow-Howell, N., Spitznagel, E., Dore, P., Proctor, E. K., \& Pescario, R. (2006). Imputing missing data: A comparison of methods for social work researchers. Social Work Research, 30(1), 1931. http://puck.naswpressonline.org/vl=21118164/ cl=13/nw=1/rpsv/cw/nasw $/ 10705309 / \mathrm{v} 30 \mathrm{n} 1 / \mathrm{s} 3 / \mathrm{p} 19$ 
Schafer, J. L., \& Graham, J. W. (2002). Missing data: Our view of the state of the art. Psychological Methods, 7, 147-177. doi:10.1037//1082989X.7.2.147

Schreiner, M., Clancy, M., \& Sherraden, M. (2002). Saving performance in the American dream demonstration: A national demonstration of individual development accounts. (CSD Report 0215). St. Louis, MO: Washington University, Center for Social Development. http://csd.wustl.edu/ Publications/Documents/ADDReport2002.pdf

Schuchardt, J., Hanna, S. D., Hira, T. K., Lyons, A. C., Palmer, L., \& Xiao, J. J. (2009). Financial literacy and education research priorities. Journal of Financial Counseling and Planning, 20(1), 84-95. http:// 6aa7f5c4a9901a3e1a1682793cd11f5a6b732d29.gri pelements.com/pdf/ schuchardt hanna hira lyons palmer xiao.pdf

Shafer, J., Elmeskov, J., \& Tease, W. (1992). Saving trends and measurement issues. In E. Koskela \& J. Paunio (Eds.), Savings behavior: Theory, international evidence, and policy implications. Cambridge, UK: Blackwell.

Sherraden, M. S. (2010). Financial capability: What is it, and how can it be created? (CSD Working Paper No. 10-17). St. Louis, MO: Washington University, Center for Social Development.

http://csd.wustl.edu/Publications/Documents/ WP10-17.pdf

Sherraden, M. S., Johnson, L., Guo, B., \& Elliott, W. (2010). Financial capability in children: Effects of participation in a school-based financial education and savings program. Journal of Family and Economic Issues. Advance online publication. doi:10.1007/s10834-010-9220-5

Solmon, L. C. (1975). The relation between schooling and savings behavior: An example of the indirect effects of education. In T. F. Juster (Ed.), Education, income and human behavior (pp. 253293). New York, NY: McGraw-Hill.

Sonuga-Barke, E.J.S., \& Webley, P. (1993). Children's saving: A study in development of economic behavior. Hillsdale, NJ: Lawrence Erlbaum.

Ssewamala, F., \& Sherraden, M. (2004). Integrating saving into microenterprise programs for the poor: Do institutions matter? Social Service Review, 78(3), 404-428. doi:10.1086/421919
Strauss, A. L. (1952). The development and transformation of monetary meanings in the child. American Sociological Review, 17(3), 275-286. doi: $10.2307 / 2088073$

Summers, L., Carroll, C., \& Blinder, A. (1987). Why is the U.S. national saving so low? Brookings Papers on Economic Activity, 1987(2), 607-642. doi: $10.2307 / 2534491$

Tucker, D. M. (1991). The decline of thrift in America: Our cultural shift from saving to spending. New York, NY: Praeger.

Waines, N. O. (1984). Development of economic concepts among Egyptian children. Journal of Cross-Cultural Psychology, 15, 49-64. doi: $10.1177 / 0022002184015001003$

Ward, S., Wackman, D. B., \& Wartella, E. (1977). How children learn to buy. London, UK: Sage.

Warnarr, M., \& Van Praag, B. (1997). How Dutch teenagers spend their money. De Economist, 145(3), 367-397.

Webley, P., Burgoyne, C. B., Lea, S.E.G., \& Young, B. M. (2001). The economic psychology of everyday life. Hove, East Sussex, UK: Psychology Press.

Webley, P., Levine, M., \& Lewis, A. (1991). A study in economic psychology: Children's saving in a play economy. Human Relations, 44(2), 127-146. doi:10.1177/001872679104400202

Webley, P., \& Nyhus, E. (2006). Parents' influence on children's future orientation and saving. Journal of Economic Psychology, 27, 140-164.doi:10.1016/ j.joep.2005.06.016

Webley, P., \& Plaisier, Z. (1998). Mental accounting in childhood. Children's Social and Economics Education, 3(2), 55-63.

Young Americans Bank. (2009). Consumer statistics. Retrieved from http://www.yacenter.org/

Young Americans Center for Financial Education. (2010). About us: Why young Americans? Retrieved from http://www.yacenter.org/ 